\title{
Barroco, hermenéutica y modernidad I
}

\author{
Luis Ignacio Iriarte \\ Universidad Nacional de Mar del Plata \\ iriarteignacio@yahoo.com.ar
}

Fecha de recepción: 27/12/2010, Fecha de publicación: 26/04/2011

<URL: http://www.studiaaurea.com/articulo.php?id=197 >

\section{Resumen}

Este texto tiene dos partes. Esta primera parte describe las ideas mediante las cuales algunos críticos, escritores e intelectuales del siglo xx comprendieron la literatura y la cultura del XvII. Nuestra hipótesis es que, en este período, hay dos perspectivas para interpretar el Barroco. Por un lado, hay autores que proponen que el Barroco retorna en la época contemporánea; por el otro lado, hay críticos que sostienen que sus características principales son inseparables del contexto histórico del 1600. En las conclusiones, se extraen algunas ideas compartidas por ambos enfoques.

Palabras clave

Barroco, crítica, modernidad

\begin{abstract}
:
Baroque and modernity hermeneutics I

This text has two parts. This first part describes the ideas by which some critics, writers and intellectuals of the $\mathrm{xx}$ century understood the literature and culture of the XVII century. Our hypothesis is that, in this period, there are two perspectives to interpret the Baroque. On one hand, some authors propose that the Baroque returns in modern times; on the other hand, there are critics who argue that its main characteristics are inseparable from the historical context of 1600. In the conclusions we draw some ideas shared by both approaches.
\end{abstract}

Key words

Baroque, criticism, modernity 
En principio, este trabajo estaba proyectado como un único texto. Pero siguiendo una sugerencia de sus revisores, lo desglosé, y de este modo pude ampliar los fundamentos que sostienen su lectura. Esta primera parte tiene el propósito de revisar algunos de los autores que se refirieron al Barroco durante el siglo xx. Se abordan, en primer término, las lecturas que se publicaron alrededor de la Primera Guerra Mundial (Heinrich Wölfflin, Werner Weisbach, Walter Benjamin, Eugenio D'Ors, Dámaso Alonso y Alfonso Reyes), y el texto avanza, por cierto que fragmentariamente, hasta fines del siglo xx, refiriéndose a los trabajos de Arnold Hauser, René Wellek, Jacques Lacan, Gilles Deleuze, José Lezama Lima, Severo Sarduy, José Antonio Maravall, Bruce Wardropper y Víctor García de la Concha, entre otros estudiosos.

Inicialmente, este panorama estaba proyectado como un mínimo estado de la cuestión. Pero me pareció justificable que se convirtiera en un texto autónomo porque su propósito era presentar una introducción que, basada en los autores recién enumerados, podría dar idea de la imagen que el siglo xx se forjó del Barroco. Según señalo en el primer apartado, durante la Primera Guerra Mundial, época en la cual comienza a elaborarse una lectura positiva del 1600, aparecen dos tendencias diferentes. Para utilizar conceptos sintéticos, me refiero a la formación y consolidación de una "hipótesis del retorno» y de una «hipótesis historicista». La primera, representada inicialmente por Wölfflin, ubica el arte del siglo XviI como un espejo para comprender la contemporaneidad. La segunda, representada esta vez por Weisbach, sostiene que el Barroco es inseparable de las características sociales, económicas, políticas y religiosas del 1600 europeo. A lo largo del siglo xx, este deslinde teórico y crítico se afianzó a través de escritores, críticos y teóricos europeos y latinoamericanos.

Estos dos tipos de lectura no deben entenderse como dos campos estrictamente separados. Cabe hablar, más bien, de inclinación hacia uno u otro de los ángulos desde los cuales se puede interpretar el Barroco. Asimismo, existen autores que, como Walter Benjamin durante la primera posguerra, ocupan un lugar intermedio. La existencia de estos contactos sugiere que se pueden extraer una serie de ideas en común. No quisiera dejar en suspenso esta cuestión, porque no se pierde nada adelantando las conclusiones. Leídos en conjunto, los autores considerados en este texto comprenden el Barroco como la expresión de una crisis general, crisis que a su vez constituye el nacimiento de la modernidad y del sujeto moderno. Estas tres ideas, nacidas no sólo de los documentos sino también de una historia autónoma de la crítica literaria, son centrales para la imagen que el siglo xx se formó del XviI.

Esta primera parte concluye con esa enumeración. La segunda parte del artículo (publicado en esta misma revista, a continuación), se propone reconstruir algunos procesos históricos a partir de los cuales se conformaron esas ideas. Pero antes de pasar a ese tema, que es el verdadero propósito de las dos partes del presente estudio, es imprescindible empezar por el recorrido al que me acabo de referir. 


\section{$\mathrm{El}$ «resurgimiento» del Barroco}

Entre las últimas décadas del siglo xIx y las primeras del xx se produjeron muchos de los cambios que marcarían nuestra modernidad. Las trincheras de la Primera Guerra Mundial enterraron el viejo mundo y, con él, millones de vidas. La Belle Epoque se agitó al ritmo del fox trot, irrumpió la democracia de masas y las revoluciones demostraron que las utopías estaban al alcance de la mano. En las capitales se aglutinaron grandes masas de población y aparecieron el teléfono, el avión y los grandes transatlánticos, innovaciones que coincidieron e incluso impulsaron las transformaciones estéticas de las vanguardias. En esta época se presentó también, por primera vez, una visión positiva de la cultura del siglo XVII y se consolidó para ella el nombre de Barroco. Asimismo, en los textos críticos de ese período comenzaron a deslindarse las dos perspectivas a las que me referí anteriormente: por un lado, se propuso el Barroco como un espejo para comprender las innovaciones estéticas y la pesadumbre de la guerra y por el otro se lo comprendió como una expresión cultural específica del siglo xvII, pieza clave para la conformación de la modernidad y de las tradiciones nacionales.

Discípulo de Jacob Burkhardt, Heinrich Wölfflin contribuyó a este restablecimiento a través de Renacimiento y Barroco (1888) y Conceptos fundamentales de la historia del arte (1915). Propuso, con estos importantes ensayos, una lectura innovadora, perdurable y que tuvo una profunda influencia a lo largo del siglo xx. Como ambos ensayos abordaron las artes plásticas, inicialmente el impacto de Wölfflin debe restringirse a la historia del arte. Pero el crítico generalizó muchas de sus ideas, convirtiéndolas en conceptos para describir la cultura en términos globales.

Ejemplo de esta forma de operar es Renacimiento y Barroco. Como anuncia el título, su propósito es describir las particularidades de los dos períodos. A fines del siglo XIX, este enfoque resulta novedoso en muchos sentidos. Ante todo, Wölfflin sostiene que el Barroco no es un apéndice decadente del Renacimiento, como hasta entonces se había entendido, sino un período que tiene sus particularidades y que, por lo tanto, merece estudiarse como una forma singular de representación. Asimismo, propone un enfoque metodológico basado en la búsqueda de conceptos en oposición. El eje, en este sentido, pasa por la antítesis ligereza/ gravedad. Según sintetiza en una frase, entre el Renacimiento y el Barroco se produjo el siguiente cambio: «las formas esbeltas y sutiles del Renacimiento dan paso a cuerpos masivos, grandes, de pesados movimientos, de marcada musculatura y abundante vestimenta» (1986: 86). Pero, según ya se dijo, Wölfflin toma esta oposición y convierte los conceptos en rasgos generales para identificar la época. Así, la gravedad del Barroco excede la plástica, ya que opera en la religión, el desaliento de los personajes literarios, la mesura de las relaciones sociales y la búsqueda de la grandeza pomposa para demostrar el poder terreno y espiritual. El historiador señala, asimismo, un importante parentesco con el arte contemporáneo mediante la gravedad ostentosa de la ópera de Richard Wagner. 
En los Conceptos fundamentales de la historia del arte Wölfflin profundiza en estos planteamientos. Nuevamente se sitúa en el campo de las artes plásticas, vuelve a darle a los rasgos formales de la pintura un alcance general y entiende que el Renacimiento y el Barroco pueden comprenderse como dos modos opuestos de representación. Pero ahora enriquece sus ideas iniciales a través de cinco reglas, mediante las cuales describe el cambio que se produjo entre una época y otra. Así, entre la plástica del Renacimiento y la del Barroco, Wölfflin registra las siguientes transformaciones: 1) de lo lineal a lo pictórico, o bien de los contornos firmes y palpables al predominio de lo visual, lo que da una obra de márgenes difusos, establecidos a partir de claroscuros; 2) de lo superficial a lo profundo, o bien de la yuxtaposición de planos en la superficie a los contrastes entre el primer plano y el fondo; 3 ) de la forma cerrada a la forma abierta, o bien de lo estático a lo dinámico; 4) de lo múltiple a lo unitario, o bien de la yuxtaposición de figuras a la subordinación de todas a un propósito central; 5) de la claridad absoluta a la claridad relativa, o bien de la completa y detallada representación de cada línea a la representación a partir de matices de luz (2006: 37-39). Más allá de las cuestiones específicas que le corresponden a cada una, detrás de estas cinco reglas se encuentra la idea de que, para Wölfflin, el Renacimiento propuso un tipo de representación racional, mientras que el Barroco se situó en la percepción. Este enfoque puede comprenderse a través de la primera regla, que señala que entre el Renacimiento y el Barroco se produjo un cambio de lo lineal a lo pictórico. En el primer caso, el artista utiliza líneas nítidas. El cuadro no muestra el mundo tal cual se percibe, sino que, retocado por el intelecto, aparece tal como debería ser. En cambio, el pintor del Barroco no corrige la realidad: reproduce lo que perciben sus ojos, transformando los contornos del Renacimiento en claroscuros y matices de luz.

En este segundo ensayo, Wölfflin también avanza en cuanto a sus primeras intuiciones sobre la sintonía entre el Barroco y la contemporaneidad. En los Conceptos fundamentales sostiene que las oposiciones entre el Renacimiento y el Barroco constituyen un esquema básico para comprender la evolución del arte a lo largo de la historia. Para Wölfflin, los dos estilos se alternan con una regularidad periódica y, por consiguiente, la historia puede comprenderse como un péndulo que se mueve entre formas de representación racionales y formas de representación situadas en la percepción. Este comportamiento no responde a cuestiones sociales, sino a variaciones del gusto. Un estilo triunfa, se automatiza y es reemplazado por la tendencia contraria. Así, al clasicismo del siglo XVI le siguió el Barroco del XVII. Luego de que éste se desgastara se produjo un retorno a la normativa de la Antigüedad. Pero con el cambio de siglo, los artistas volvieron a un tipo de arte cercano al Barroco, primero con el romanticismo y luego con el impresionismo.

Poco después de los Conceptos fundamentales apareció El barroco, arte de la contrarreforma (1921). En ese texto, Werner Weisbach abrió una perspectiva diferente para el estudio del siglo XVII. En lugar de referirse a los aspectos formales, se colocó en el clima de la Gran Guerra. Según sostiene en la presentación del 
volumen, esa dramática «situación espiritual» motivaba revisar el Barroco como una forma de conservar el patrimonio de Occidente durante los apocalípticos años en los que se encontraba el mundo:

Escrito en años de guerra, de revolución y de duras pruebas -comenta Weisbach en 1920-, este libro se esfuerza en ascender a ese dominio de lo espiritual y lo universal, el único que permite liberarse de opresoras cadenas y saltar por encima de todo límite estrecho y de toda barrera arbitraria. La conservación de este inalienable imperio puede ser, para los alemanes, un consuelo y una satisfacción en su destino (1948: 53).

Al igual que Wölfflin, Weisbach se ocupa de las diferencias que existen entre el Renacimiento y el Barroco. Pero, con un método basado en la psicología, la sociología y la estilística, piensa el arte como una expresión de los hombres en un período histórico en particular. Si bien Weisbach no elimina del todo la idea de que el siglo XVII puede funcionar como espejo del drama contemporáneo, al acentuar las condiciones sociales y políticas presenta una perspectiva historicista, mediante la cual comprende que, independientemente de las semejanzas, el Barroco tiene características específicas que únicamente se encuentran en el 1600 europeo.

En el Renacimiento, según Weisbach, se impuso una actitud crítica hacia la Iglesia. El humanismo se levantó contra la escolástica y el dogmatismo medieval. La búsqueda ardiente de una renovación del catolicismo condujo a la Reforma Luterana. Se impuso, asimismo, una estetización de todos los valores. Pero desde mediados del siglo Xvi se registra para Weisbach un profundo cambio en cuanto al clima espiritual. Las luchas religiosas y el fin de la universalidad católica, las luchas dinásticas de los soberanos y el asalto y saco de Roma por las fuerzas imperiales pusieron fin a la pasada confianza y amenazaron la estabilidad de los valores esenciales. Se propagó, así, una corriente de pesimismo y, en consecuencia, «los hombres buscaron de nuevo en su propia intimidad y en la autoridad de la Iglesia apoyo y protección» (1948: 57). Como respuesta a esta crisis, la Iglesia definió una nueva política cultural en el marco del Concilio de Trento (1545-1563). Para Weisbach, Trento no fue sólo una reacción contra la Reforma, sino también una respuesta a los conflictos espirituales surgidos del colapso del humanismo. La Contrarreforma propuso, así, la conducción de los creyentes a los valores esenciales de la cristiandad y por lo tanto buscó transformar el pesimismo en «un fin positivo que satisficiese las necesidades espirituales» (1948: 58). Para esto, reanudó la tradición dogmática de la escolástica, reforzó los elementos tradicionales de la enseńanza de la Iglesia y se esforzó por cortar de raíz los abusos contra los cuales había reaccionado el protestantismo. Consecuente con estas reformas, el Concilio subordinó el arte a los fines propagandísticos de la cristiandad y de este modo definió los rasgos característicos de la estética del Barroco.

En principio, en El origen del drama barroco alemán, Walter Benjamin persiguió propósitos similares. Como Weisbach, en ese texto Benjamin se esfuerza en comprender las características históricas del período. Además, entiende que se trata de una época, concretamente fechada, que contribuyó notablemente a la 
tradición alemana. Para plantear estos propósitos, en su tesis Benjamin destaca la novedad de su enfoque. Deja en claro que si bien el romanticismo y la filología habían hecho un trabajo notable en cuanto al estudio de la lengua y la tradición nacional, le habían restado importancia al drama barroco. Para los románticos, la luminosidad de William Shakespeare y Pedro Calderón de la Barca había opacado a los autores alemanes, en la medida en que, en comparación con esos modelos, poco habían logrado en términos estéticos. Para la filología, ocupada en la formación popular de la lengua y por lo tanto en las historias folklóricas, el Barroco no era interesante, en la medida en que había sido un tipo de arte autoritario, dirigido por el Estado. En su tesis, Benjamin se propone saldar esta deuda. Pero no considera que los críticos estuvieran equivocados en cuanto a la imperfección estética del drama barroco alemán. Por el contrario, ratifica esa idea. Sólo que, tras una ardua discusión teórica, afirma que los dramaturgos alemanes, si bien no habían logrado emular con vitalidad el teatro español, sí habían comprendido de qué se trataba, esforzándose en llevarlo a la práctica. Fracasaron estéticamente, pero tuvieron éxito en tanto, a pesar de sus limitaciones, consiguieron plasmar la forma, o bien expresar la idea de lo que era el drama barroco. Benjamin hizo del defecto virtud: si por un lado el drama barroco era una parte del patrimonio alemán, por el otro su ejecución imperfecta y su impostada formalidad lo convertían en un caso incomparable para el estudio de la cultura del siglo xvII.

Pero si de un lado Benjamin planteó una perspectiva historicista, desde otro ángulo se situó cerca de Wölfflin y consideró que existían importantes vínculos entre el siglo xviı y la contemporaneidad. Benjamin señala, en este sentido, que el espíritu alemán de la posguerra podía compararse con un enfermo que se encuentra bajo los efectos de la fiebre. El convaleciente transforma las palabras que oye en imágenes de su delirio, del mismo modo que «el espíritu de nuestro tiempo echa mano de las manifestaciones de culturas remotas en el tiempo o en el espacio para arrebatárselas e incorporarlas fríamente a sus fantasías de la época» (1990: 38). Así, la irrupción del expresionismo, con sus luces y sus sombras, motivó una rehabilitación del Barroco. Benjamin entiende que la época de la posguerra representaba una etapa de decadencia porque abusaba del recurso enfermizo al pasado y porque privilegiaba el formalismo, dejando de lado el contenido espiritual:

Las creaciones literarias de estas dos épocas -afirma Benjamin- no surgen de la existencia en el ámbito de la comunidad, sino del hecho de que con la violencia de su estilo amanerado tratan de disimular la falta de productos de valor en el terreno de las letras. Pues, al igual que el Expresionismo, el Barroco es una época en la que una inflexible voluntad de arte prevalece sobre la práctica artística propiamente dicha. Así sucede en los denominados períodos de decadencia (39).

Con esto hemos llegado al punto desde el cual podremos avanzar y no hace falta que extendamos estas glosas. Entre fines del siglo XIX y principios del xx se produjo una recuperación del Barroco. Pero a la vez se trazaron dos lineamientos 
diferenciados. En primer lugar, se encuentra en esa época lo que hemos llamado una «hipótesis del retorno». Según esta perspectiva, representada por Wölfflin, el Barroco constituye un momento crítico, pero éste a la vez se comprende a partir de su capacidad de repetirse y volver. Así, las formas de representación del siglo XVII retornan cuando se conmueven las formas consolidadas en el transcurso del siglo XviII. Wölfflin es explícito en este sentido. En su texto le dedica un apartado de sus conclusiones a lo que llama "El problema del retorno", evidentemente porque así lo exige su propuesta de la alternancia periódica de los estilos.

En Weisbach se dibuja una segunda perspectiva. En su texto demuestra que, debajo de las similitudes, existen grandes diferencias entre los siglos XVII y XX. La época del Barroco está marcada por la escolástica y el neoplatonismo, inserta en una sociedad en la que la burguesía incipiente todavía se mantiene debajo de la aristocracia y la principal demanda de los productos artísticos proviene de la Iglesia. Por esta razón, tiene poco que ver con un período artístico definido por las rupturas de la vanguardia, la reivindicación contundente de la autonomía literaria y un mundo fracturado por la guerra, la masificación de las ciudades y la mercantilización de las costumbres y la cultura. En este sentido, si Weisbach encuentra sintonías entre la crisis social y cultural del siglo Xvir y el clima espiritual de la Gran Guerra, esto no lo desvía de su propósito de reconstruir los sentidos históricos del Barroco.

Benjamin ocupa un lugar intermedio. Para él, el Barroco es una época que desde su derrumbe estético había permanecido en las sombras, ruina que aguardaba ser reconstruida y puesta a la luz por hombres pertenecientes a una época afín como la de la primera posguerra. Si bien tendremos ocasión de ver nuevos representantes de esta doble actitud, en general las dos lecturas tendieron a separarse en el transcurso del siglo xx. A eso se hará referencia a continuación.

\section{La hipótesis del retorno}

Los críticos y escritores del siglo xx no se identificaron exclusivamente con uno u otro de los puntos de vista recién deslindados. Cuando pasamos a los textos concretos, el retorno y la reconstrucción se encuentran igualmente presentes, aunque hay un acento en alguno de los dos. Este matiz es fundamental para comprender la perspectiva del retorno, a la que se hará referencia en este apartado. Ninguno de los que se colocan en este punto de vista omite una reconstrucción histórica de la cultura del siglo xvir. Pero la cuestión pasa por el hecho de que sitúan el retorno como el eje a partir del cual interpretar tanto las singularidades del 1600 como las de la contemporaneidad.

Un ejemplo fructífero en este sentido es El origen de la literatura y el arte modernos (1965) de Arnold Hauser. En ese texto, Hauser se refiere al Manierismo, concepto que busca diferenciar con la mayor claridad posible del Renacimiento y del Barroco. Pero es importante tomarlo en cuenta porque, sin dejar de pro- 
poner una importante reconstrucción socio-cultural del período, el punto de vista que adopta es el del retorno. Para el historiador, entre los siglos XVI y XVII se produjo una crisis profunda, que afectó a todos los estratos de la cultura. En política, religión, economía y, por supuesto, en arte y literatura, las viejas ideas colapsaron, produciéndose un interregno de inestabilidad. Fue entonces cuando emergieron los primeros brotes del capitalismo, la figura del genio artístico, la secularización de la vida y la alienación. Para Hauser, esta primera crisis del mundo moderno tiene rasgos inseparables de los siglos XVI y XVII. La revolución copernicana, la autonomización de la política, la separación luterana del mundo sagrado y la producción en serie son todas innovaciones que conmovieron la mentalidad del 1600 y luego se naturalizaron. Pero justamente en este aspecto se puede comprender el impacto que tiene el hecho de que Hauser considere que existe un retorno de esta situación. Para el historiador, la crisis que se vivió entre el 1500 y el 1600 constituye el nacimiento del capitalismo y la sociedad burguesa y es un modelo para las que se sucedieron a lo largo de la historia occidental. Así, cada vez que las ideas colapsaron, como sucedió entre los siglos XIx y xx, reflotó el manierismo original. En este sentido, lo que para Hauser distingue la crisis del 1600 es que vuelve y se repite, como si fuera uno de los motores de la modernidad.

En términos formales, este tipo de abordaje se repitió a lo largo del siglo xx. Pero es importante destacar que cambiaron las interpretaciones sobre la cuestión de la crisis y por lo tanto se transformaron los vínculos entre el Barroco y la contemporaneidad. Así, desde los años cincuenta comenzaron a imponerse las propuestas teóricas de la filosofía y el psicoanálisis franceses. Emergió, con esto, una férrea crítica a la esencialidad del hombre y a todo tipo de planteos trascendentales, que repercutieron en la imagen que este sector, centrado en el retorno, propuso del siglo XviI. A fines del 1900, las interpretaciones del Barroco se unieron, finalmente, con las reflexiones sobre la posmodernidad, el estallido de los significantes y la globalización del mercado de bienes culturales.

El antecedente más importante de estas interpretaciones se encuentra en la obra de Jacques Lacan. Desde fines de los años cincuenta Lacan comenzó a referirse a la cultura del siglo Xvil como una expresión modélica para exponer su teoría del sujeto. Pero fue en el seminario Aun (1972-1973), y puntualmente en la clase del 8 de mayo de 1973, cuando declaró su adscripción al Barroco. Fiel al estilo de su madurez, la exposición de Lacan es elíptica, no acusa referencias bibliográficas y tiende a la fragmentación del aforismo en lugar de utilizar razonamientos encadenados. Pero en las frases centrales de esa clase se percibe una clara influencia de Weisbach. Así, Lacan propone que «El barroco es inicialmente la historieta, el anecdotario de Cristo» (2001: 130). El tono irónico, que tiene una gran importancia en lo que respecta a sus consideraciones sobre Dios, no desmiente la precisión que ostenta esa frase si la leemos a partir de la reconstrucción del historiador alemán. Para Weisbach, una de las claves del Barroco se encuentra en el vínculo que existe entre la pintura religiosa, verda- 
dera dominante del período, y los ejercicios espirituales de Ignacio de Loyola. Como se sabe, los ejercicios se llevaban a cabo durante aproximadamente un mes, período en el cual los creyentes hacían oraciones y meditaban en silencio, representándose vivamente las etapas de la vida de Jesús, con un especial énfasis en las escenas de la Pasión. Según Weisbach, la dramática pintura religiosa del Barroco fue, en parte, una realización artística de estos ejercicios. Es decir, los pintores proporcionaron cuadros en los que exponían las imágenes en las que se concentraban los creyentes. Así, como señala Lacan, el Barroco es la historieta de Jesús: está conformado por una serie de cuadros que muestran su vida, con especial énfasis en la Pasión.

Lacan señala, asimismo, que esta organización de la pintura tiene como propósito el gobierno de los sujetos. Según sugiere en otra de las frases centrales de su texto, «El barroco es la regulación del alma por la escopia corporal» (140). En otras palabras, el arte de la Contrarreforma buscaba gobernar las almas al poner ante los ojos de los espectadores las escenas sufrientes de los mártires y de Jesús. Como se puede ver en un rápido recorrido por la pintura religiosa del período, los pintores representan cuerpos atravesados por el dolor y el goce. Con esto demuestran, para Lacan, la verdad de Dios. Pero no lo hacen de manera directa. Por el contrario, los pintores ponen figuras humanas que sufren el martirio o que contemplan en un rapto místico su divina presencia. Es decir, muestran a Dios a través de su incidencia en los cuerpos. Por otra parte, según advierte Lacan, en ese mundo de dolor y goce nunca aparece representada la relación sexual. Esta ausencia, sumamente significativa para una pintura que bordea lo erótico, no se explica por el pudor. Muestra, en cambio, que entre los sujetos no hay relación sexual, es decir, complementariedad. Así, el arte católico del Barroco pone de manifiesto que la plenitud, representada en ausencia por la relación sexual, no se encuentra en este mundo terreno, sino en un Dios que no tiene presencia terrenal. Los mártires, los místicos, el propio Jesús, gobiernan las almas en la medida en que le muestran a los espectadores la castración y la elevación de esa plenitud al Otro, sitio estructural en el cual el cristianismo coloca a Dios.

Pero Lacan no propone esta sagaz reconstrucción con un propósito meramente arqueológico. Si está del lado de la hipótesis del retorno del Barroco esto se debe a que considera que el psicoanálisis volvió a demostrar esta estructura cristiana. En otras palabras, el siglo xviı puso ante los ojos de la humanidad su más profunda verdad. El siglo XviII la sepultó debajo de la razón y el progreso científico. Hasta que Freud volvió a descubrir la estructura a fines del xix. Pero Lacan le dio un giro al catolicismo, en tanto demostró que el Otro (Dios) no es un ser, sino una necesidad estructural, desde el principio vacía. Así lo demuestra en la siguiente frase de Aun: «A mí me parece manifiesto que el Otro, presentado en la época de Instancia de la letra como lugar de la palabra, era una manera, no diré de laicizar, pero sí de exorcizar al buen Dios» (2001: 100-101). En definitiva, más allá de estas consideraciones sobre el Otro, para Lacan el mundo contemporáneo puede comprenderse como un retorno del Barroco. 
En El pliegue (1989), Gilles Deleuze inauguró una nueva lectura. Según su perspectiva, el Barroco puso en primer plano el pliegue como método de comprensión de las cosas en general y del arte en particular. Al ser tan abstracta, la idea cautiva por su poder explicativo. Desde el embrión al recién nacido, desde las cadenas de ADN, en doble hélice, a la curvatura del espacio-tiempo, el universo puede definirse de acuerdo con los materiales puestos en juego y las formas mediante las cuales éstos se pliegan. Para Deleuze, el Barroco teorizó estas ideas a través de las mónadas leibnizianas y lo hizo materialmente palpable con la arquitectura. Un edificio representativo del siglo xviI, según Deleuze, puede describirse por la independencia entre el interior y el exterior. En efecto, los arquitectos pusieron un particular cuidado en aislar la recámara interna, disimulando las ventanas por las que ingresa la luz, y colmándola de cuadros y decoraciones; asimismo, le dieron independencia a la fachada. Sin embargo, en las dos partes del edificio se emplearon materiales y técnicas que, si bien presentan variaciones en vistas al resultado, son similares. De este ejemplo Deleuze concluye que en ambos casos se trata del mismo pliegue, sólo que, para la fachada y para el interior, se utilizaron regímenes diferentes de plegado.

Este interés por la arquitectura se explica porque es un ejemplo para comprender al hombre. Basta con pensar la fachada como el cuerpo y el interior como el alma, según el modelo de las mónadas, para tener una teoría del sujeto. Lo interesante, en este caso, es que se elimina completamente el supuesto de una esencia interior para poner en primer plano que la subjetividad no es otra cosa que un efecto del pliegue que opera universalmente en todas las cosas. A su vez, Deleuze enmarca esta tesis en una historia de la cultura que, a grandes rasgos, había definido Hauser en la obra antes citada. En efecto, si el Barroco descubrió el pliegue como mecanismo de construcción universal, esto significa que operó a lo largo de la historia. Sólo que los pliegues se mantuvieron controlados hasta el siglo Xvir. Con el Barroco se liberaron, para luego volverse a cerrar. Como Hauser, Deleuze explica el retorno como una crisis epistemológica general. Pero, a su vez, comprende el Barroco como una liberación crítica que se repite a lo largo de la historia y que por lo tanto está en condiciones de volver.

\section{El retorno visto desde América Latina}

En América Latina, la hipótesis del retorno tuvo una especial fortuna. En este sentido es importante recordar a los cubanos José Lezama Lima, Severo Sarduy y Alejo Carpentier y al argentino Néstor Perlongher. Podemos sintetizar sus enfoques a partir de los dos escritores mencionados en primer lugar. Ante todo, hay que decir que Lezama Lima comenzó a publicar en los ańos treinta, durante el ascenso de don Luis de Góngora en las consideraciones críticas españolas. Por otra parte, y sobre todo a partir de sus revistas, mantuvo un intenso contacto con los escritores hispánicos, particularmente con Juan Ramón Jiménez, pero 
también con Rafael Alberti, Jorge Guillén, Pedro Salinas y María Zambrano. Independientemente de estas influencias, Lezama Lima desarrolló una obra singular y, por cierto que tomando en cuenta las intensas relecturas de las primeras décadas del siglo xx, elaboró una propuesta insoslayable sobre el Barroco, sobre todo a través de dos importantes ensayos: "Sierpe de don Luis de Góngora» (1953) y La expresión americana (1957). Aunque ocupan un lugar menor, también es útil recordar «Soledades habitadas por Luis Cernuda» $\mathrm{y}$ "Un poeta mexicano del siglo XviI", ambos publicados en la revista Grafos, el primero en 1936 y el segundo en 1937.

Leídos en conjunto, los ensayos de Lezama proponen dos ejes para comprender la cultura del siglo xvII. En primer lugar, en consonancia con los horizontes fijados por Weisbach, para Lezama el Barroco debe entenderse como una de las claves para la conformación de la tradición nacional. En su caso, este tema se incluye en los rasgos específicos de la cultura americana, continuando en este sentido las propuestas que Pedro Henríquez Ureña había sintetizado en Las corrientes literarias en la América Hispana (1945). Para Lezama, la clave se encuentra en el disfrute. En «Un poeta mexicano del siglo XVII», imagina a Luis de Sandoval y Zapata, el escritor al que se refiere en la nota, «entre los aromas del café y el laberinto de su paladar voltario» (1981: 149). En La expresión americana retoma este entorno gozoso y lo contrasta con las severidades que por esa época se instalan en la mentalidad peninsular. Lezama recuerda el espléndido ideal de vida de Carlos de Sigüenza y Góngora, tan opuesto a los apuros económicos y la malograda suerte de su famoso tío cordobés. Sin utilizar el concepto, para Lezama el Barroco de Indias es el arte vital y gozoso de la transculturación, mientras que el peninsular demuestra las amargas notas de los tiempos finales.

Pero si por un lado comprende la cultura del siglo XVII como una expresión histórica de la identidad americana, por el otro propone un retorno en la contemporaneidad. En «Soledades habitadas por Luis Cernuda» acerca, de manera en muchos casos forzada, los versos de Góngora y los de Cernuda. Esto le permite establecer una versión propia del Barroco. Con un tácito rechazo de La deshumanización del arte de José Ortega y Gasset, Lezama defiende la vigencia de Góngora, pero rechaza el mero juego verbal. Según entiende, el retorno del Barroco únicamente tiene sentido si su retórica admirablemente compleja se utiliza para expresar los sueños y los deseos descubiertos por Cernuda. En otros términos, hay una vuelta a Góngora. Pero el manejo admirable del lenguaje que éste tenía debe utilizarse para poner en palabras cuestiones como el paraíso perdido de la infancia, el reverso onírico de la vida y el origen cosmogónico de esa segunda naturaleza que habita el hombre y que se llama cultura. En lugar de los juegos de palabras y las estructuras formales, Lezama plantea un Barroco sustancial.

Estas dos perspectivas (el Barroco como expresión de los significados profundos del hombre y el Barroco como eje de la identidad americana) se integran en «Sierpe de don Luis de Góngora». En ese ensayo, opone las perspectivas poéticas de Góngora y San Juan de la Cruz. Lezama comprende a Góngora a 
partir de los planteos que Dámaso Alonso había establecido en «Claridad y belleza de las Soledades» (1927). En efecto, para Lezama el poeta alza los objetos para que reciban el rayo luminoso de su incomparable capacidad metafórica. En cambio, San Juan es un escritor de los misterios sagrados y la oscuridad. Así, «El escándalo del aire, producido por los objetos luminosos de don Luis, vuelca colérica el ave cetrera sobre la propia parábola de su identificación, mientras que el disfraz aportado por San Juan, llena los sentidos de poblaciones y plazas nocturnas» (1988: 80). Para Lezama, esta división significó para España la pérdida de la gran poesía. Se trata de «un dualismo, es cierto que en una de las formas más grandiosas alcanzadas por la cultura occidental, entre el gongorino rayo de reencuentro y reconocimiento y las bienaventuradas aguas placenterias de San Juan» (82). Las posibilidades contemporáneas del Barroco se encuentran en la unión de esos dos estilos: «Será la pervivencia del barroco poético español las posibilidades siempre contemporáneas del rayo metafórico de Góngora envuelto por la noche oscura de San Juan» (82). Pero la unión sólo es posible en territorio americano. Escribe Lezama, hablando del rayo metafórico de Góngora y la nueva naturaleza americana: «Si aquel rayo se destruyese sobre los nuevos calendarios y máscaras, sobre las nuevas vegetativas somnolencias, Góngora hubiese vencido aquel irritable desgano, que parece entorpecer la suerte y riesgo final de las Soledades» (87). Pero no se trata, como sostiene Carpentier en «Lo barroco y lo real maravilloso", de la simple expresión de la extrañeza americana. Por el contrario, para Lezama la extrañeza vincula al hombre con eso que le es desconocido y lo determina profundamente (lo sagrado, lo onírico, el mundo de la infancia). Escribe en "A partir de la poesía»: «La imantación de lo desconocido es por el costado americano más inmediata y deseosa. Lo desconocido es casi nuestra única tradición» (1988: 387). En Lezama, el retorno del Barroco es una recuperación de las capacidades retóricas de Góngora como forma de expresar lo desconocido, las zonas sagradas que, particularmente presentes en América, constituyen la sustancia plena del hombre y la cultura.

Sarduy propuso un segundo retorno hispanoamericano del Barroco. El escritor comenzó a publicar en los años '50 y, con el triunfo de la Revolución, alternó la poesía y el ensayo con la propaganda a favor del nuevo gobierno surgido en 1959. A fines de ese año se marchó con una beca para estudiar historia del arte y, por razones que nunca quedaron del todo claras, no volvió. Instalado en Francia, trabó una relación amorosa, que duraría toda la vida, con François Wahl, editor de Editions du Seuil y responsable de la publicación de los Escritos de Lacan ${ }^{1}$. La obra de Sarduy es indisociable de esta trayectoria. Sarduy toma de Lezama el gusto por la sobreabundancia y la importancia de lo americano. Pero a la vez reinterpreta estas ideas a partir de Lacan. En sus

1. Sobre François Wahl, cf. La biografía de Elizabeth Roudinesco sobre Lacan (2005: 467-484). 
ensayos, la sobreabundancia se debe a la autonomía del significante, que juega libremente sobre el vacío, lo cual lo lleva a la conclusión de que el siglo XviI descubrió por primera vez en la historia que el hombre es un efecto del juego de las representaciones.

Su ensayo más importante es Barroco (1974). En ese texto, Sarduy elabora una imagen del Barroco basada en la idea de que el siglo Xvi vivió una crisis epistemológica, cultural y existencial. Para exponer esta idea, se apoya en un uso metafórico de la cosmología mediante el cual divide la historia de la cultura en tres segmentos: la cosmología antes del Barroco, que va de Platón a Galileo, la cosmología barroca de Kepler, centrada en el siglo xvir, y la cosmología después del Barroco, representada por las teorías opuestas del Big Ban y el Steady State. La tesis que recorre esta visión es simple. Entre el Renacimiento y el Barroco la cosmología ptolemaica se derrumbó. Hasta que se estabilizaron las nuevas concepciones, el hombre se encontró perdido. Según Sarduy, la época contemporánea sufrió un cataclismo similar. Las innovaciones de la ciencia, la ruptura de las vanguardias, la masificación de las ciudades y el descubrimiento del inconsciente conmovieron el sustento del hombre. Uno de los tantos efectos de esta inestabilidad consistió en que los escritores, artistas e intelectuales buscaron en el pasado momentos similares. Por esta razón hubo un retorno del Barroco.

El eje del ensayo está planteado en la oposición entre Copérnico y Kepler. Sarduy pudo tener en mente las antítesis de Wölfflin o las vueltas de la crisis de Hauser. Pero lo cierto es que la idea pertenece a Lacan. En el seminario Aun, Lacan se refiere a los dos astrónomos como una forma de explicar la sentencia de Freud de que con su obra había dado un giro copernicano ${ }^{2}$. Según comenta en la clase del 16 de enero de 1973, habría que corregir eso que en el fondo le parece un error. Lacan recuerda que Copérnico demostró que la Tierra giraba alrededor del Sol. Pero este cambio no afectó la estructura. Según Lacan, ratificó la idea de centro, estableciendo ahora, con pruebas empíricas, que todo el universo gira alrededor de un eje. Por eso afirma que «La subversión, si es que existió en alguna parte y en algún momento, no está en haber cambiado el punto de rotación de lo que gira sino en haber sustituido un gira por un cae» (2001: 56). Eso es lo que hizo Kepler:

El punto álgido, como se les ocurrió percibir a algunos no es Copérnico, sino más bien Kepler, debido a que en él la cosa no gira de la misma manera: gira en elipse, y eso ya cuestiona la función del centro. En Kepler las cosas caen hacia algo que está en un punto de la elipse llamado foco, y, en el punto simétrico, no hay nada. Esto ciertamente es un correctivo respecto a esa imagen de centro (56).

2. Si bien, antes de sacar Barroco, Sarduy no tuvo ocasión de leer Aun (éste se editó, recién, en 1975), pudo acceder a estas ideas a través de la asistencia a las clases, o bien gracias a versiones extraoficiales, proporcionadas por apuntes o bien por las grabaciones que manejó la editorial du Seuil. 
Para Lacan, esto está profundamente ligado al descubrimiento del inconsciente, porque también en este caso lo que se produjo es un cuestionamiento de la idea de centro. En Lacan, este planteo tiene dos vertientes. En primer lugar, el sujeto puede comprenderse a partir de la interacción de dos focos, el inconciente y la conciencia, que aplastan el círculo copernicano. En segundo término, lo que gira no es la plenitud del significado, sino el vacío de los significantes. Con ambas operaciones, Lacan destituye la idea de que el hombre es una esencia, para convertirlo en un efecto de la estructura. Sarduy retoma esta perspectiva. En su caso, el Barroco tiene como eje la subversión del sujeto y la concepción del mundo como una red de significantes sociales y culturales en dispersión.

Tras Sarduy, varios escritores y críticos retomaron estos planteos. En La era neobarroca (1987), el italiano Omar Calabrese sostiene que el retorno del Barroco está regulado por este mundo estallado de significantes que para él constituye la contemporaneidad. Los textos referidos a la obra de Sarduy son igual de representativos. En el volumen La estrategia neobarroca (1987), Gustavo Guerrero reconstruye los caminos por los cuales se fueron configurando una imagen esencial del Barroco, representada por Lezama Lima, y otra ligada a los estudios estructuralistas, ejemplificada por Sarduy. Su texto, referido a este último autor, abona esta tesis, al referirse a las formas, las estructuras, los sistemas significantes que sustentan la obra del escritor y que remiten tanto a la contemporaneidad como a la visión contemporánea que tenemos del Barroco. El argentino Néstor Perlongher se identifica también con este retorno de la cultura del siglo XviI. Para el poeta, que se apoya en la filosofía de Deleuze, «Hay un flujo que recorre toda la lengua española, que se vuelve a desencadenar desde Cuba, desde Lezama, que es la resurrección del barroco» (2004: 317).

Por último, y aunque excede los límites del siglo xx, se pueden citar dos trabajos que responden a la hipótesis del retorno. En «La ideación barroca» (2003), perteneciente al importante volumen Barroco, Pedro Aullón de Haro separa con gran nitidez el Barroco histórico del estilo barroco. Propone, por consiguiente, que existe un período y a la vez un tipo de arte transhistórico. Pero en ninguno de los dos casos se trata sólo de una forma de representación. Para Aullón de Haro, el barroco es una modelación de lo dionisíaco. Por eso retorna cada vez que entran en crisis los períodos clásicos o apolíneos de la cultura. En el mismo campo del retorno se ubica el más reciente Barroco y neobarroco en la narrativa hispanoamericana (2008). En ese volumen, Cristo Rafael Figueroa Sánchez abona la tesis de la crisis como causa de la emergencia de la cultura del siglo XviI: «tanto el manierismo como el barroco históricos resultan de la crisis del clasicismo renacentista; ambos estilos son anticlásicos, ambos rompen la concepción antropocéntrica y ambos obedecen a una voluntad de monumentalidad» (2008: 39). Tomando como referencia L'interieur et l'exterieur (1968) de Jean Rousset, el crítico sostiene que «el gusto del siglo xx por el barroco se origina en un sentimiento de parentesco entre las dos épocas» (47). Para Figueroa Sánchez, el retorno se debe a la crisis de los sistemas estéticos y perceptuales del siglo xx y el 
rol que juegan «las redes y circuitos del mercado hiperglobal de signos estéticos, con sus flujos y reflujos característicos» (50).

Como se puede ver, la hipótesis del retorno tiene un desarrollo amplio y productivo a lo largo del siglo Xx. Por supuesto, los trabajos considerados no son los únicos y, como lo demuestran los últimos textos citados, la perspectiva continúa vigente hasta la actualidad. Pero de este mínimo recorrido se pueden extraer algunas características comunes. Ante todo, la imagen del Barroco cambia sensiblemente a lo largo del siglo. En las primeras décadas está organizada alrededor del impresionismo y las vanguardias, las innovaciones tecnológicas y el clima sombrío de la guerra. Hacia mediados de siglo comienza a formarse una imagen distinta, que se corresponde con la subversión del sujeto inaugurada por Lacan, perspectiva que se continúa hasta Deleuze. Al filo del 2000, el Barroco comienza a aparecer como un dispositivo de lectura adecuado para comprender la posmodernidad. Por cierto, este carácter multifacético tiende a restarle significado al concepto, transformándolo en una palabra operativa para múltiples propósitos. Pero a la vez no hay que perder de vista que, en el fondo, todas las identificaciones surgidas de la hipótesis del retorno sitúan como eje la cuestión de la crisis. Los críticos y escritores recién considerados comprenden que el siglo XVII puede caracterizarse como una época de conmoción cultural y existencial. Así, independientemente de que enfoquen el drama de la guerra, la subversión del sujeto o el mercado hiperglobal, entienden que todas estas manifestaciones responden a una crisis equiparable a la que se vivió en el siglo Xvir. Si por una parte hay una amplificación de los significados a los que la palabra puede referirse, por el otro la hipótesis del retorno no pierde nunca ese eje a partir del cual comprende el Barroco y su vuelta en la contemporaneidad.

Dicho esto, toca ahora hacer un breve repaso por la reconstrucción histórica, asunto al que nos dedicaremos a continuación.

\section{La reconstrucción histórica del Barroco}

En España se dan relevantes contribuciones a la hipótesis del retorno. Uno de los representantes más tempranos, enormemente influyente por otra parte, es Eugenio D'Ors, con el volumen Lo barroco, antología de textos que el intelectual sacó en Francia, en 1935. El eje de ese importante libro es «La querella de lo barroco en Pontigny", una mezcla de ensayo y crónica, basado en una de las discusiones que se dieron en la abadía de Pontigny, a donde D'Ors concurría desde 1920, centrada en el problema del Barroco. En ese texto, el ensayista retoma la idea de Wölfflin de que las formas clásicas y barrocas se alternan con periodicidad. Pero, con un temperamento más radical e iconoclasta, el intelectual redobla la apuesta y plantea que lo clásico y lo barroco constituyen categorías universales, situadas en una suerte de cielo platónico, desde el cual descienden para realizarse en la historia. Hay una sola idea de lo barroco 
y una sola idea de lo clásico. A la vez, existen diferentes encarnaciones. Para ratificarlo, D'Ors propone una lista, escrita con un latín tan innecesario como inventado, mediante el cual enumera los diversos subtipos de lo clásico y lo barroco que sintetizan (o amenazan con sintetizar) el conjunto de la historia de la cultura a escala mundial.

Pero si bien Espańa cuenta con este notable representante del retorno, tal vez uno de los rasgos característicos de su crítica y de la que se vinculó con ella sea la convergencia en una hipótesis historicista. Podemos ver su emergencia a través de Dámaso Alonso. En principio, se puede considerar que los poetas de la generación del 27 continuaron la perspectiva del retorno. Como señala Oreste Macrí (1960), Dámaso Alonso leyó a Góngora a partir de la serie conformada por Paul Verlaine, Stephan Mallarmé, Rubén Darío, Jorge Guillén y Gerardo Diego, de acuerdo con la idea de que "gongorismo, barroquismo y poesía pura se identifican como momentos históricos de una naturaleza eterna de poesía española inmanente en ellos» (1960: 36) ${ }^{3}$. Pero si bien la lectura de Macrí es muy interesante, en el reciente El Barroco de los modernos (2009) Aurora Egido ha demostrado que en Dámaso Alonso hay una temprana transformación del Barroco en una cuestión de la historia de la literatura (233). En este sentido, si bien desde cierto punto de vista sus primeros trabajos pueden pensarse como representantes de lo que hemos llamado la "hipótesis del retorno", también perfilan una perspectiva orientada a la reconstrucción de los significados históricos del siglo XviI.

Un ejemplo de esta ambivalencia es "Góngora y la literatura contemporánea», fechado en 1927 y publicado en 1932. En ese texto, Dámaso Alonso reconoce la importancia de Verlaine y Darío para la relectura de Góngora. Pero trata a ambos con una implacable severidad. Según juzga, Verlaine admiraba sólo «intuitivamente» al poeta de las Soledades. Rubén Darío escucha y retransmite, casi como si fuera un autómata de las novedades parisinas. Así, Alonso sostiene que "Toda esta primera fase de la "vuelta a Góngora» se caracteriza por su apriorismo, su indocumentación, su carácter snob y su superficialidad» (1978: 753-754). Una opinión similar le merece el acercamiento entre Góngora y Mallarmé. Ciertamente, concede Alonso, entre ambos escritores pueden trazarse a primera vista vínculos importantes, que se basan en la complejidad y los esfuerzos metafóricos. Pero las diferencias son igual de abismales. Góngora es un retórico que toma conceptos tradicionales y los lleva al extremo, aunque mantiene siempre una lógica exacta, que por más que aplace la realidad, nunca rompe sus amarras con ella; Mallarmé puede también entenderse como «la sustitución de un mundo de realidades por uno de representaciones», pero "es un

3. Oreste Macrí distingue con una notable claridad los usos contemporáneos del Barroco. Por otra parte, en las conclusiones de ese artículo presenta una tesis en la cual destaca que el método de lo que hemos llamado el retorno tiene una importante y valiosa repercusión en los estudios sobre el siglo xviI. 
mundo inexistente, que se está formando y deshaciendo en todo momento de intuición poética» (737).

Así, su trabajo tiene el propósito de desacoplar a Góngora de los escritores del modernismo hispanoamericano y del simbolismo y del decadentismo francés. En contraste, destaca que él y sus compañeros generacionales fueron los primeros que estaban en condiciones de conocer de manera satisfactoria la obra del poeta, separándose «de la ciega y postiza admiración, sin conocimiento verdadero, de los escritores de 1900» (768). A pesar de esta identificación, Dámaso Alonso sostiene, sin embargo, que el vínculo entre Góngora y su generación no proviene de la influencia directa, sino de la afinidad. Puede haber, sin duda, coincidencias, como el predominio de las metáforas y la búsqueda de perfección; pero estas coincidencias «no son fundamentales, sino adjetivas, y no vienen de Góngora, sino van a coincidir con Góngora, para cobrar en su ejemplo augusto nuevo aliento y nuevo impulso. Góngora no influye, reinfluye» (768). Incluso en un artículo tan temprano como éste, Dámaso Alonso distingue la literatura del siglo Xvir y la poesía contemporánea. Hay coincidencias, pero éstas sólo son parciales. Así prepara un tipo de lectura, que más tarde él mismo se encarga de llevar a cabo, que tiene como horizonte la reconstrucción del significado histórico de Góngora y el Barroco.

Otro ejemplo de este progresivo deslinde se encuentra en Alfonso Reyes. Como se sabe, el mexicano fue un temprano gongorista. Entre 1916 y 1921 Reyes colaboró con Raymond Foulché-Delbosc en la edición del manuscrito Chacón. Publicó además, en 1923, una edición del Polifemo en la colección «Índice» (dirigida por Juan Ramón Jiménez), «donde se ha modernizado la ortografía y se ha aclarado la puntuación para uso del lector moderno, en términos que no hubieran sido propios de una publicación exclusivamente erudita», por lo que, según él entiende, «sólo debe considerarse como un intento de dar, al público literario general, una edición bella, cuidadosa y accesible del poeta cordobés» (Reyes 1996: 156). La mayor parte de sus artículos de esa época son filológicos. Reyes cataloga las obras de Góngora, coteja manuscritos, discute la interpretación dudosa de algún verso y compendia bibliografías. Pero incluso en este tipo de estudios iniciales, Reyes se coloca más bien de lado de las explicaciones a partir del retorno. Así, en sus textos tempranos propone a Góngora como un modelo para que la literatura contemporánea logre acercarse a la modernidad de Mallarmé. En «De Góngora y de Mallarmé» (1920), una reseña sobre los estudios comparados entre ambos autores, comienza afirmando que «Había que esperar a que la juventud de lengua española - que, por de contado, tenía noticia de Mallarmé- alcanzara también un grado de familiaridad suficiente con su tradición propia para decidirse a abrir los libros de Góngora» (1996: 158). Comenta luego los trabajos de los críticos Francis de Miomandre y Zdislas Milner: «Acierta [el primero] al asegurar que Góngora y Mallarmé caen, en el cielo estético, más cerca uno de otro que no lo estaban de sus respectivos contemporáneos» (161); mientras que de Milner extrae conclusiones incluso más provechosas, porque pese a ser temperamentalmente di- 
ferentes, había algo que los aproximaba: «la fuente ideal, el estado psicológico del artista, lo consciente y premeditado del esfuerzo, la religión poética», así como también «la oscuridad no intentada por sí misma, que resulta como una necesidad interior de ambas tentativas» (161).

Pero si inicialmente ratificó la hipótesis del retorno, Reyes fue desplazándose hacia una perspectiva historicista sobre la literatura del Barroco. Desde muy temprano bregó porque se releyeran los comentaristas del siglo XviI. En «Necesidad de volver a los comentaristas» (1920) comienza a deslindar una lectura literaria de otra filológica. Según sostiene, la primera no necesita volver a los significados históricos: lo que hay en Góngora «de virtud puramente lírica o de raro hallazgo verbal no requiere notaciones históricas ni mitológicas»; pero enseguida afirma que si verdaderamente se quiere saber qué es lo que dijo el poeta cordobés, es imprescindible volver a los comentaristas, porque «nadie entiende ni podrá entender nunca, mediante los solos recursos de la sensibilidad y del gusto, una abrumadora multitud de pasajes del Polifemo, las Soledades, el Píramo y Tisbe, el Panegírico y otras cosas» (1996: 150). Esta división se profundiza en «Sabor de Góngora» (1928). En ese texto, muy cercano a "Góngora y la literatura contemporánea», Reyes deslinda la lectura estética de la lectura erudita: «La alusión erudita a veces aparece tan tramada con el pensamiento poético, que si cazamos la alusión, de paso hemos dado muerte al encanto mismo de la poesía» (1996: 192). La lectura filológica aspira a reconstruir las alusiones mitológicas y el significado que las palabras tenían en el siglo XVII; en cambio, la lectura estética se contenta con el deleite anacrónico de lo que un verso dice en el actual estado de recepción. A partir de la década de los treinta, esta división se afianza cada vez más.

Para rastrear los cimientos de esta perspectiva es imprescindible desviarse brevemente del campo español. En el famoso e influyente «El concepto de barroco en la investigación literaria» (1946), René Wellek impone la condición de que la palabra «Barroco» únicamente tiene sentido si se refiere tanto al estilo como a la ideología. Ello supone una especificación significativa. La palabra, empleada en el sentido de Wellek, se convierte en un término técnico que designa la cultura que se desarrolla a lo largo del siglo Xvir. Por consiguiente, deja de lado los usos modernos, que sólo toman en cuenta el estilo. Asimismo, esta articulación de Wellek abre la posibilidad de pensar un sistema que comprenda las diferentes expresiones culturales, no sólo la literatura, sino también las artes plásticas, el urbanismo, el pensamiento, el sistema político y las artes de la guerra.

La gran realización de este tipo de enfoques es La cultura del barroco (1975). En ese extenso ensayo, José Antonio Maravall desplaza la idea del Barroco como estilo y sostiene que la palabra se refiere al conglomerado de expresiones artísticas, pensamientos y aun disposiciones sentimentales que constituyen la cultura que se desarrolló a lo largo del siglo xviI. El volumen supera las explicaciones de la Primera Guerra, particularmente las de Wölfflin y Weisbach. En lugar de comprender el Barroco como el resultado de un cambio motivado por un sistema autónomo 
de reglas de representación, como el primero, o de entenderlo, como el segundo, a partir del influjo de la Contrarreforma, Maravall sostiene, de manera más amplia, que las manifestaciones de la pintura y los rebuscamientos de la poesía, que los textos de los arbitristas y las estrategias bélicas y de represión concebidas para operar dentro de las ciudades, obedecen y responden a la idea de que, durante el siglo XVII, Europa atravesó una crisis económica y social. La cultura del Barroco es una respuesta a esa desestabilización del viejo orden medieval.

Por cierto, la tesis no es nueva. Hauser la había formulado para comprender el fenómeno del manierismo y Eric Hobsbawm la había presentado en el famoso artículo "La crisis general de la economía europea en el siglo XVII» (1954). Pero debido a la importantísima documentación que maneja y a su refinada capacidad de análisis, Maravall avanza inequívocamente en el estudio del Barroco. Como se lee en Hobsabwm, los conflictos del siglo XviI se deben a la notoria retracción económica europea. Maravall demuestra, además, que esto motivó una profunda crisis social. En 1600 se rompieron los lazos tradicionales de sociabilidad, se perdió la confianza en los poderes explicativos de los sistemas culturales y el hombre, al menos en los círculos letrados, tuvo una aguda conciencia de la decadencia. Verdadero interregno entre la sociedad tradicional y el capitalismo, para Maravall el Barroco puede explicarse a partir de la fuerte tensión entre las monarquías y la oleada de protestas que despertó la crisis. Escribe sobre este último aspecto: «Muchos historiadores no dudan en aplicar hoy el moderno concepto de "revolución» a los trastornos que se están dando en Europa, desde el siglo XVI, en que tantas de las alteraciones señaladas comienzan su proceso" (1975: 70). Como las protestas fueron en aumento, se montó una extensa operación social tendiente a contener esas fuerzas que amenazaban con descomponer el orden tradicional:

Para responder a todo este múltiple y complejo hervor de disconformidad y de protesta (en unas circunstancias en que los medios de oposición se habían hecho más sutiles, en que el volumen demográfico en las ciudades había aumentado y con ello la población participante en las manifestaciones contra la opresión había crecido en amenazadora proporción) la monarquía absoluta se vio colocada ante dos necesidades: fortalecer los medios físicos de represión y procurarse medios de penetración en las conciencias y de control psicológico que, favoreciendo el proceso de integración y combatiendo los disentimientos y violencias, le asegurasen su superioridad sobre el conjunto (112).

Esta tesis, aparte de que une estilo e ideología y descubre un tronco común para las diferentes expresiones culturales, le permite a Maravall establecer rasgos particulares para Espańa. La corona española se encontraba a la cabeza de Europa y la necesidad de mantener el orden tradicional era en su caso más apremiante que en las demás monarquías. A su vez, la burguesía no tenía la suficiente fuerza como para encauzar las oleadas revolucionarias que se agitaron durante el siglo xvir. Así, mientras que en Inglaterra y Francia la crisis dio paso 
a un ascenso y luego a un triunfo de la burguesía, en Espańa este camino quedó cercenado. Paradójicamente, la fuerza de su monarquía y de su cultura fueron las causas de su atraso posterior.

Parte de estas ideas vuelven a encontrarse en la introducción al tercer tomo de la Historia crítica de la literatura española (1983). En ese texto, Bruce Wardropper retorna al requisito de Wellek de que, para que sea válido, el término "Barroco» debe referirse tanto al estilo como a la ideología. Esto hace que en muchos sentidos su texto sea una continuación del de Maravall. Pero en Wardropper hay varios hallazgos insoslayables. En primer lugar, define con gran precisión el estilo, la ideología y el vínculo que hay entre los dos. Para Wardropper, el estilo se identifica con el conceptismo y lo ideológico con la conciencia de los hombres del siglo Xviı de que se encontraban en una época de decadencia. El vínculo entre ambos tiene una elegante simpleza. Como la decadencia de la época se encuentra en una profunda desconexión de los elementos sociales, el estilo se encarna en el conceptismo, que busca la coincidencia oppositorum. Entre los hallazgos de Wardropper se puede destacar, además, la existencia de una continuidad entre el Renacimiento y el Barroco. Para los años ochenta, este tema no era novedoso (recordemos que para Dámaso Alonso la obra de Góngora debía verse como una intensificación de la poesía renacentista). Pero el acento en la continuidad le permite presentar una idea del Barroco lo suficientemente rigurosa como para que sea específica de la cultura del siglo XviI y, a la vez, lo suficientemente amplia como para evitar la datación drástica del período. Si bien el crítico no utiliza la palabra, a partir de su texto se puede comprender el Barroco como una tendencia. Ésta se desarrolla en el Renacimiento, llega a su punto máximo con la interacción de conceptismo y conciencia de la decadencia social y se diluye cuando comienzan a imponerse las poéticas neoclásicas.

En «Barroco: categorías, sistema e historia literaria» (1993), Víctor García de la Concha propone una lectura que permite cerrar el mínimo recorrido emprendido en esta primera parte del trabajo. En esa oportunidad, el crítico le presta importancia al fenómeno del «neobarroco» a partir de un diálogo que entabla con los textos de Sarduy y Calabrese. Pero en lugar de volver a una concepción transhistórica, mantiene la idea de que el Barroco está restringido a la cultura del siglo XviI. Sólo que lo entiende como un sistema literario conformado por estilos, formas, temas y recursos, cuyo eje no es la crisis, como en Maravall y Wardropper, sino el desplazamiento del mundo y la centralización del lenguaje. Esta idea le permite comprender las recuperaciones parciales que se fueron sucediendo a lo largo de la historia. Así, García de la Concha pone de manifiesto que mientras el siglo XviII permaneció orientado por una ideología racional, los precursores del Romanticismo volvieron a desplazar la realidad cotidiana para abrir el campo de la fantasía. Este acercamiento se acentuó en los siglos XIX y XX, primero con el Romanticismo, que sostuvo que la palabra tiene un poder intrínseco aparte de sus capacidades representativas, y luego con el Simbolismo y el Creacionismo. 
Con esto hemos dado vuelta este mínimo recorrido por la perspectiva de la reconstrucción histórica. Si intelectuales como Deleuze, Lacan y Sarduy tomaron el punto de vista del retorno y desde ese lugar propusieron una lectura del siglo xviI, García de la Concha toma la palabra desde el campo opuesto para tratar de comprender las expresiones contemporáneas. Esta simetría justifica que pasemos a extraer algunas conclusiones.

\section{Las ideas sobre el Barroco}

Los autores comentados en este trabajo constituyen una muestra de un siglo de debates alrededor del Barroco. De más está decir que es necesario utilizar y subrayar la palabra minimo para el corpus elegido. El orden que propuse puede resumirse en unas pocas frases. Como es ampliamente conocido, a fines del siglo XIX y principios del xx la crítica comenzó a valorar positivamente el Barroco y se estabilizó el significado de esa palabra. Los autores de esa época (Wölfflin, D’Ors, Weisbach, Benjamin, Alonso y Reyes) se propusieron reconstruir las particularidades artísticas y literarias del siglo xvir. Algunos de ellos, al menos al principio, también trataron de demostrar que este renovado interés se debía a las cercanías entre el Barroco y la contemporaneidad. Según vimos a lo largo de este trabajo, estas dos perspectivas fueron configurando dos campos separados. En principio, como en Reyes, este deslinde puede comprenderse como una distinción entre las lecturas literarias y las lecturas académicas. Pero proyectada en el siglo, esta oposición simplifica demasiado. En este texto traté de organizar las lecturas a través de dos hipótesis. Por un lado, hay una hipótesis del retorno, que supone una vuelta del Barroco como paso previo a la interpretación, y por el otro hay una hipótesis de que el Barroco tiene sentidos inseparables del siglo Xvir.

Como ejemplos podemos recordar a Sarduy y Maravall, dos autores contemporáneos y claramente opuestos entre sí. Sarduy es un representante de la hipótesis del retorno, no sólo porque efectivamente plantea la vuelta a través del neobarroco, sino porque su preocupación no pasa por un relevamiento textual del siglo XVII, que de hecho se reduce sólo a las figuras centrales y a los textos más conocidos, sino que su interés está enfocado en la situación crítica de la contemporaneidad. En el ángulo opuesto se encuentra Maravall. Entre las primeras ediciones de $B a$ rroco (1974) y La cultura del Barroco (1975) media tan solo un año. Pero la actitud de Maravall no puede ser más opuesta a la de Sarduy. Si bien su reconstrucción tiene entre sus propósitos explicar el problemático presente español, esta atención no cambia su trabajo puntilloso con los documentos ni la búsqueda consecuente de darle al Barroco sentidos específicos e inseparables del 1600.

Estos dos lineamientos cuentan con autores insoslayables y, a lo largo de su desarrollo, han logrado esclarecer aspectos fundamentales del siglo XVII. Por esta razón, tiene poco sentido establecer una preferencia por alguno de ellos. Por otra parte, la hipótesis del retorno y la hipótesis historicista no constituyen dos frentes inconciliables. Las cosas nunca funcionan de una manera tan drástica y prolija. 
Más bien, el retorno y la reconstrucción son dos extremos que dibujan un campo lleno de matices. Así, entre Sarduy y Maravall se pueden situar varios autores. Dentro de los comentados en este texto, es importante destacar a Benjamin, Hauser, Lezama Lima y García de la Concha. En los cuatro hay una doble consideración. Por un lado, sostienen que el siglo XvII forma parte de la historia de la modernidad y, por el otro, que es un período instructivo para comprender la situación estética, cultural y aun política del presente. Como lo revelan estos autores intermedios, la cuestión pasa por percibir la línea prioritaria en la cual cada autor se apoya para comprender el pasado. En el caso de la hipótesis del retorno (Hauser y Lezama Lima), la cultura del siglo Xvir se entiende a partir de la idea de que muchos de sus rasgos específicos están en condiciones de volver al presente. En el caso de la reconstrucción histórica (García de la Concha, pero también Benjamin), los autores se basan por el contrario en la tesis de que ésta es el producto de las condiciones sociales, económicas y aun existenciales del XvII europeo. Esto significa, por lo tanto, que todo vínculo con el presente está supeditado a las diferencias entre las dos épocas en cuestión.

Los puentes que trazan estos autores intermedios revelan que los dos enfoques, si bien se apoyan en presupuestos opuestos, son indisociables. Esta inseparabilidad pone en primer plano que ambos fueron los responsables de la conformación de la imagen que el siglo xx se hizo de la cultura del XviI. Podemos comprender este aspecto a partir, ya no de las diferencias, sino de las ideas por ambos compartidas. En primer lugar, para todos los autores considerados en este texto, el Barroco constituye la expresión de una crisis. Por cierto que este fenómeno tiene un sentido diferente, por ejemplo, en Maravall y Sarduy. Maravall utiliza el concepto para comprender la época de decadencia que se abatió sobre Europa, decadencia que concluyó con el antiguo orden y que llevó al hombre a las puertas de la sociedad burguesa. En cambio, Sarduy entiende que la crisis se abate sobre la comprensión del mundo. Según sostiene, lo que se quiebra es el orden mediante el cual el hombre pensaba su existencia. Pero esto no quita que coincidan en que el Barroco es el emergente cultural de una crisis epistemológica y social.

En segundo término, y de manera correspondiente, todos los autores comentados en este texto consideran que esta crisis del siglo XVII constituye el nacimiento de la modernidad. Y esta segunda idea cambia si se la contempla desde el punto de vista del retorno o si se lo hace desde la perspectiva de la reconstrucción. Así, para Wölfflin la dinámica moderna del arte nace de la ruptura de la estética del Renacimiento por parte de la pintura barroca. En cambio, para autores como Weisbach, Maravall o Wardropper, el siglo xvir constituye el comienzo de la modernidad porque en esa época surgieron varios conflictos que, si bien en su realización concreta inicial son inseparables del 1600, se convierten en algunos de los nudos problemáticos del proceso histórico hasta la actualidad. Pero nuevamente, como sucede con el concepto de "crisis", esto no invalida que ambos enfoques sostengan la idea de que en ese período se asistió al nacimiento de un tiempo nuevo, en el cual todavía estaríamos involucrados. 
En tercer lugar, todos los autores considerados en este trabajo sostienen que en ese período surgió el hombre moderno. Para recuperar los aportes de Lacan al tema, el sujeto del Barroco se concibe como un sujeto escindido. Por supuesto, en su formulación radical esta idea únicamente se encuentra en Lacan y Sarduy. Pero en los otros autores ésta también aparece bajo la idea de que el hombre del Barroco es un hombre fuertemente limitado por cuestiones externas a su voluntad. Así lo podemos ver, ante todo, en Hauser. En Hauser hay una clara comprensión de que el hombre del siglo XviI se percibe limitado por órdenes que están más allá de su voluntad: la inaccesibilidad de lo sagrado, el surgimiento de una economía capitalista y el descentramiento del mundo a través de la revolución copernicana. Benjamin propone otro tanto al referirse al fin de la escatología cristiana. En igual sentido, Lezama Lima funda su literatura en el vínculo del hombre con un espacio inaccesible de lo sagrado. Weisbach plantea algo similar mediante la reconstrucción del Barroco como una respuesta a los límites críticos ante los que se encontró la confianza renacentista. Wölfflin, con su historia del arte sin artistas, supone la idea de que, parafraseando a Lacan, el pintor es pintado por la pintura. Esta concepción también se encuentra en los críticos y escritores que, desde mediados de siglo, plantearon una reconstrucción histórica del Barroco. Maravall y Wardropper observan que lo característico de la crisis del XviI es que el hombre se ha dado cuenta de la dramática conmoción en la que vive. Hay, por primera vez, una conciencia de que el mundo no es como debería. Esa diferencia entre la realidad concreta y los ideales inspirará por cierto las revoluciones. Pero no deja de ser la constatación de que en el mundo existe una frontera entre lo que es y lo que debería ser. En fin, en García de la Concha el Barroco puso por primera vez en juego la idea de que las palabras siempre dicen mucho más de lo que parecen. Pueden apuntar a un orden sagrado o desenvolverse en un mar de evocaciones sensoriales, pero en cualquier caso constituyen una frontera entre un orden inexpresable y esta realidad cotidiana.

En suma, a partir de los textos comentados en este trabajo se pueden extraer cinco ideas: 1) el Barroco es un espejo del presente; 2) el Barroco es una de las claves para la conformación de las tradiciones nacionales; 3 ) el Barroco constituye el nacimiento crítico de la modernidad; 4) el Barroco es la expresión de una crisis; 5) el Barroco es el nacimiento del sujeto escindido de la modernidad. Como vimos, las dos primeras dividen aguas, pero hay matices y a la vez existen autores (los primeros trabajos de Reyes y Alonso, los textos de Lezama Lima, Weisbach, Benjamin, Hauser y García de la Concha) que se sitúan en una zona intermedia. Independientemente de estas diferencias teóricas, lo cierto es que estas ideas son claves para la imagen que el siglo xx se formó del Barroco.

Pero lo más importante es que estos conceptos no son verdades descubiertas tras el olvido al que se había condenado la cultura del 1600. Más bien habría que entenderlos como ejes de interpretación que, tras una compleja elaboración, se convirtieron en las herramientas intelectuales mediante las cuales el siglo $\mathrm{xx}$ cinceló lo que podríamos considerar su Barroco. Así podemos verlo, en primer lugar, en las consideraciones sobre el espejo de la historia y los planteos sobre la 
tradición nacional. La primera aparece con claridad en los ensayos de Wölfflin y la segunda tiene su punto de origen en las reivindicaciones románticas del teatro del siglo Xvir. En este sentido, no surgieron de un desocultamiento de la verdad, sino que son ejes mediante los cuales la crítica moderna organizó los textos y les dio sentido. Otro tanto cabe decir del nacimiento del sujeto moderno como sujeto escindido, tesis que en términos teóricos resulta muy visible a partir de Sigmund Freud. En fin, las ideas de que el Barroco es la expresión de la primera gran crisis y de que constituye el origen de la modernidad son propuestas que, basadas en el supuesto de que el período es el umbral entre el feudalismo y el capitalismo, tampoco pueden entenderse como datos descubiertos tras la renovación del interés en la cultura del siglo XVII, sino como elaboraciones tardías mediante las cuales el presente organizó su pasado.

No me es posible comprobar en este ya largo texto los anclajes históricos de cada una de estas ideas. Pero sí es admisible sugerir algunos apuntes para la última cuestión y, de paso, confirmar aunque sea parcialmente lo que se acaba de decir. Como observa Maravall, la palabra crisis, con el sentido de derrumbe de un orden y nacimiento de uno nuevo e insospechado, estuvo disponible muy tardíamente. El historiador señala que, aunque el término comenzó a emplearse en el siglo XvII, era de uso específico en el léxico médico. Para Maravall, esto no significa que la idea no existiera. Es más, debido a que el sentido estaba connotado por su pertenencia a la medicina, los escritores del Barroco se acostumbraron a proponer soluciones al estado de decadencia a través de metáforas extraídas de los campos semánticos de la cura y la enfermedad. Pero incluso con estos matices es difícil sostener completamente las ideas que en este sentido propone Maravall. En realidad, en el Diccionario de autoridades (1729) la palabra significa «juicio que se hace sobre alguna cosa, en fuerza de lo que se ha observado y reconocido acerca de ella». El significado médico, que Maravall remonta al siglo XvII, aparece en la edición de 1780: «Mutación considerable que acaece en alguna enfermedad, ya sea para mejorarse, o para agravarse más el enfermo». En 1852 se le añade a éste la idea de que «por extensión se dice del momento decisivo de un negocio grave y de consecuencias importantes». En 1899, tres ediciones después, se especifica un significado para la frase "crisis ministerial», acercándola a la idea de interregno: «Situación de un ministerio cuando todos o parte de sus individuos pretenden abandonar sus puestos por hallarse en disidencia entre sí o con el jefe del estado». Recién en 1970 se ofrecen dos definiciones que coinciden con nuestro uso actual: «1. Mutación importante en el desarrollo de otros procesos, ya de orden físico, ya históricos o espirituales. 2. Situación de un asunto o proceso cuando está en duda la continuación, modificación o cese». En contraste, lo que está disponible en el siglo XVII es la palabra "decadencia». Pero «decadencia» no es un sinónimo exacto de «crisis». Esta última palabra significa fin de un período y apertura a un futuro nuevo. En cambio, «decadencia» supone declinación, fin de ciclo, curva descendente. Más aún, la raíz de la palabra significa repetición de fenómenos que se suceden regularmente. Por otra parte, este sentido cíclico está presente en el Dic- 
cionario de autoridades. En 1737 se lee, así, la siguiente definición: «Declinación, descaecimiento, menoscabo, principio de la ruina de algún Imperio, Monarquía y otra cosa semejante». Ciertamente, como observa Maravall, los hombres del siglo XVII fueron concientes del momento de retracción en el que les tocó vivir. Pero la idea al uso, como lo será todavía durante el 1700 y el 1800, es la de decadencia. Es decir, la de ruina.

En lo que respecta al Barroco, la palabra "crisis» puede pensarse como una reinterpretación, que vuelve positivo lo negativo, de las tesis sobre la decadencia y la corrupción de la literatura, que ganaron el centro de los debates durante el 1700, con nombres fundamentales como Ignacio de Luzán, Blas Nasarre, Agustín Montiano y Luyano y Luis Velázquez. Así, al transformar la decadencia en crisis, los críticos e historiadores, desde la Primera Guerra en adelante, pudieron comprender el período como una etapa de transición entre el feudalismo y el capitalismo. Por esta razón se puede decir que surge tanto del estudio de los documentos como de las discusiones contemporáneas entre historiadores y críticos, que tienen una importante autonomía. Esto es algo que se encuentra en el propio Maravall. El historiador no desconoce que la comprensión del pasado se basa en la imposición de una serie de ideas para ordenar los documentos y otorgarles de ese modo un sentido. Así podemos comprender el uso de la palabra crisis: se trata del verdadero eje mediante el cual organiza y le da sentido al siglo XviI.

En síntesis. El siglo xx conformó una imagen sumamente rica del Barroco. Hubo una perspectiva del retorno y un lineamiento que concibe como propósito la reconstrucción histórica del XVII. Pero independientemente de esta diferencia, los dos puntos de vista coinciden en tres ideas, que un futuro trabajo podría ampliar, y que podemos considerar como los cimientos de la imagen que los críticos e historiadores se hicieron del Barroco. La cultura del siglo xviI es la expresión de una crisis económica y social y dio nacimiento a la modernidad y al sujeto escindido. Estas interpretaciones son el resultado de un largo debate que se dio a lo largo de la historia intelectual al menos desde el siglo xviII. Desde luego, esto no invalida, ni mucho menos, los importantes trabajos críticos a los que se hizo mención. Como claramente sostiene Maravall, el pasado únicamente tiene sentido si se lo lee desde una perspectiva global, que no necesariamente tiene que haber sido pensada por los hombres y mujeres que vivieron en ese tiempo. Pero la identificación de esas ideas obliga a indagar el proceso histórico a través del cual se fueron conformando hasta llegar a definirse como los ejes para la comprensión de la cultura del siglo xvir. Esto no significa que, tras un estudio de esas características, comprendamos mejor el pasado. Pero sí podremos ver la compleja trama gracias a la cual se conformó la imagen con que lo comprendemos. Asimismo, la forma cambiante mediante la cual se entendió el siglo XviI nos permitiría estudiar desde un ángulo distinto ese proceso complejo que llamamos modernidad. De más está decir que un estudio como ése excede a quien estas palabras escribe. Pero quisiera aunque solo fuera plantear su admisibilidad. Ése y no otro es el propósito de la segunda parte de este trabajo. 


\section{Bibliografía}

Alonso, Dámaso, "Góngora y la literatura contemporánea», en Obras Completas V, Madrid, Gredos, 1978, 725-770.

—, "Claridad y belleza de las "Soledades»», en Obras Completas V, Madrid, Gredos, 1978, 293-317.

Aullón de Haro, Pedro, «La ideación barroca», en Barroco, Pedro Aullón de Haro y Javier Pérez Baso, Madrid, Verbum, 2004, 21-58.

Benjamin, Walter, El origen del drama barroco alemán, Madrid, Taurus, 1990.

Calabrese, Omar, La era neobarroca, Madrid, Cátedra, 1999.

Carpentier, Alejo, «Lo barroco y lo real maravilloso», en Ensayos, La Habana, Letras Cubanas, 167-193.

Deleuze, Gilles, El pliegue. Leibniz y el barroco, Barcelona, Paidós, 1989.

D'Ors, Eugenio, Lo barroco, Madrid, Tecnos, 1993.

Egido, Aurora, El Barroco de los modernos. Despuntes y pespuntes, Valladolid, Cátedra Miguel Delibes, Universidad de Valladolid, 2009.

Figueroa Sánchez, Cristo Rafael, Barroco y neobarroco en la narrativa hispanoamericana, Medellín, Editorial Universidad de Antioquía - Editorial Pontificia Universidad, 2008.

García DE LA Concha, Víctor, «Barroco: categorías, sistema e historia literaria», en Estado actual de los estudios sobre el Siglo de Oro, Manuel García Martín, Salamanca, Ediciones Universidad de Salamanca, 1993.

Gautier, Theophile, Voyage en Espagne, París, Charpentier, 1856.

Guerrero, Gustavo, La estrategia neobarroca, Barcelona, Ediciones del Mall, 1987.

Hauser, Arnold, El origen de la literatura y el arte modernos, Madrid, Guadarrama, 1974.

Henríquez Ureña, Pedro, Las corrientes literarias en la América Hispana, México, FCE, 1964.

Новзвашм, Eric, «La crisis general de la economía europea en el siglo XVII», en En torno a los orígenes de la revolución industrial, México, Siglo XXI, 1988.

Lacan, Jacques, Seminario. Libro 20. Aun (1972-1973), Buenos Aires, Paidós, 2001.

Lezama Lima, José, «Soledades habitadas por Luis Cernuda», en Imagen y posibilidad, Ciro Bianchi Ross, La Habana, Letras Cubanas, 1981, 137-143.

—, «Un poeta mexicano del siglo XVII», en Imagen y posibilidad, 148-150.

—, «Siepre de don Luis de Góngora», en Confluencias, Abel Prieto, La Habana, Letras Cubanas, 1988, 69-91.

—, "A partir de la poesía», en Confluencias, 1988, 386-399.

—, La expresión americana, Irlemar Chiampi, México, Fondo de Cultura Económica, 1993.

MACrí, Oreste, «La historiografía del barroco literario español», Thesaurus, 15, (1960), 1-70. 
Maravall, José Antonio, La cultura del Barroco, Barcelona, Ariel, 1975.

Ortega y Gasset, José, La deshumanización del Arte, Madrid, Espasa Calpe, 2004. Perlongher, Néstor, Molina, Daniel, «Paseando por los mil sexos (entrevista)», en Papeles insumisos, Adrian Cangr y Reynaldo Jiménez, Buenos Aires, Santiago Arcos, 2004.

Reyes, Alfonso, Tres alcances a Góngora, en: Obras Completas VII, México, FCE, 1996.

Roudinesco, Elisabeth, Lacan. Esbozo de una vida, historia de un sistema de pensamiento, Buenos Aires, Fondo de Cultura Económica, 2005.

Sarduy, Severo, Barroco, en Obra Completa II, François Wahl - Gustavo Guerrero, Buenos Aires, Archivos/Sudamericana, 1999, 1195-1262.

Wardropper, Bruce, Historia y crítica de la literatura española III. Siglos de Oro: Barroco, Barcelona, Crítica, 1983.

Weisbach, Werner, El Barroco, arte de la Contrarreforma, Lafuente Ferrari, Madrid, Espasa-Calpe, 1948.

WELLEK, René, «El concepto de barroco en la investigación literaria», en Historia literaria. Problemas y conceptos, Barcelona, Laia, 1983, 51-95.

Wölfflin, Heinrich, Conceptos fundamentales en la historia del arte, Madrid, Espasa-Calpe, 1985.

—, Renacimiento y Barroco, Barcelona, Paidós, 1986. 